\title{
Nail hyperpigmentation in ACTH-secreting pituitary adenoma (Cushing's disease) and its resolution after successful trans-sphenoidal excision
}

\author{
Mark Anthony Santiago Sandoval $\mathbb{1}^{1,2}$ Racquel Gorgonio Bruno ${ }^{2}$
}

'Department of Physiology, College of Medicine, University of the Philippines Manila, Manila, Philippines

${ }^{2}$ Division of Endocrinology, Diabetes and Metabolism, Department of Medicine, College of Medicine and Philippine General Hospital, University of the Philippines Manila, Manila, Philippines

\section{Correspondence to} Dr Mark Anthony Santiago Sandoval;

mssandoval1@up.edu.ph

Accepted 3 April 2020
Check for updates

(c) BMJ Publishing Group Limited 2020. No commercial re-use. See rights and permissions. Published by BMJ.

To cite: Sandoval MAS, Bruno RG. BMJ Case

Rep 2020;13:e234905 doi:10.1136/bcr-2020234905

\section{DESCRIPTION}

Hyperpigmentation is a known physical examination finding in conditions where adrencorticotrophic hormone (ACTH) is excessive. This is because ACTH shares the same affinity with $\alpha$-melanocyte-stimulating hormone (MSH) for the melanocortin-1 receptor (MC1R). MC1R is considered the most important melanocortin receptor that regulates melanogenic activity. This shared affinity of ACTH and MSH for MC1R is because these two peptides share the common four-amino acid sequence, His-Phe-Arg-Trp, which is necessary for melanotropic activity. ${ }^{1}$

In Cushing's disease, the excessive ACTH is from a functioning pituitary adenoma, and this leads to various manifestations of hypercortisolism or Cushing's syndrome.

A 37-year-old Filipino woman reported a 3-year duration of amenorrhoea and 5-month duration of progressive weight gain, facial roundedness, acne, leg weakness, easy bruisability and blurring of vision. On physical examination, she was hypertensive at $155 / 99 \mathrm{~mm} \mathrm{Hg}$, had central obesity, moon facies, facial plethora, buffalo hump, violet abdominal striae, ecchymoses and bipedal oedema. Generalised skin hyperpigmentation was difficult to ascertain because of the normal brown skin colour of Filipinos. Her fingernails and periungual tissues were particularly hyperpigmented, as shown in figure 1 .

Performance of the $1 \mathrm{mg}$ overnight dexamethasone suppression test showed non-suppression of 8 -hour serum cortisol at $551 \mathrm{nmol} / \mathrm{L}$ (normal suppression: $\quad<50 \mathrm{nmol} / \mathrm{L})$. Plasma adrenocorticotrophic hormone (ACTH) was elevated at $82.67 \mathrm{pg} / \mathrm{mL}$ (normal $<40 \mathrm{pg} / \mathrm{mL}$ ). MRI of the head showed a $46 \times 41 \times 70 \mathrm{~mm}$ lobulated, heterogeneously enhancing sellar-suprasellar mass with cystic and necrotic components. These investigations led to a diagnosis of ACTH-secreting pituitary macroadenoma (Cushing's disease).

After successful trans-sphenoidal excision of the pituitary mass, plasma ACTH level significantly decreased to $1.96 \mathrm{pg} / \mathrm{mL}$. Histopathological evaluation confirmed pituitary adenoma. However, immunostaining for ACTH and Ki-67 was not done. There was subsequent $8 \mathrm{~kg}$ weight loss and improvements in blood pressure, vision, facial plethora, acne, lower extremity motor strength and bipedal oedema. Six months postsurgery, plasma ACTH was $18 \mathrm{pg} / \mathrm{mL}$ and 8 -hour serum cortisol was $499 \mathrm{pmol} / \mathrm{L}$ in the absence of any exogenous

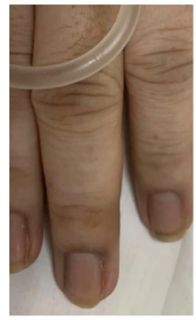

Baseline

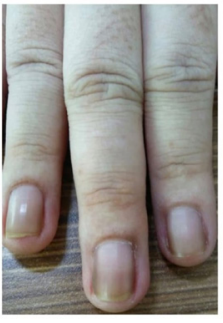

4 mos. post-op

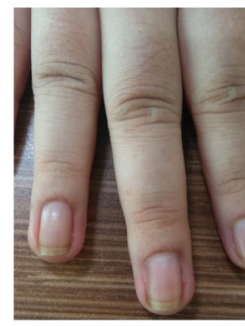

6 mos. post-or
Figure 1 At baseline, there is hyperpigmentation of the fingernails and periungual tissues. By the fourth month postsurgery, there is now a gradient in the colour of the nail, with the distal part being hyperpigmented and the proximal part being of normal colour. By the sixth month postsurgery, the entire nail is not hyperpigmented anymore, and there is lightening of the periungual tissues. post-op, postoperation.

\section{Patient's perspective}

I am happy that my appearance has changed after my surgery. I have now lost weight. I now feel more beautiful as my skin appears lighter and my pimples have lessened. My doctor has pointed out that my nails and surrounding parts have darkened as well. We are happy that the colour has normalised already. I have allowed my case to be written so that others will learn from my experience.

\section{Learning points}

- Adrenocorticotrophic hormone (ACTH), together with $\alpha$-melanocyte stimulating hormone, stimulates the melanocortin-1 receptor, which controls melanogenesis. Excessive ACTH then leads to hyperpigmentation.

- Hyperpigmentation can affect the nails of patients with ACTH-secreting pituitary adenoma. After successful treatment, the nail that grows out does not appear hyperpigmented anymore.

- We can inform our patients that the bothersome changes in their appearance, nail hyperpigmentation in particular, can change with successful treatment. 
glucocorticoid. Hence, she did not require glucocorticoid replacement. Likewise, free thyroxine was $18 \mathrm{nmol} / \mathrm{L}$, and thyroid-stimulating hormone was $0.05 \mu \mathrm{IU} / \mathrm{mL}$, not necessitating thyroid hormone replacement.

The photograph taken 4 months postsurgery (see figure 1) showed a colour gradient with the distal part of the nail to be hyperpigmented while the proximal part already appeared normal. By 6 months postsurgery, the entire nail is not hyperpigmented anymore. Likewise, the periungual tissues were now less pigmented. This clearly demonstrates that with successful treatment, there is resolution of nail hyperpigmentation as the nail subsequently grows out and that there is lightening of the periungual tissues.

We can thus inform our patients that these physical changes which are bothersome for them do change if the condition is successfully treated.

Twitter Racquel Gorgonio Bruno @rac_bruno
Acknowledgements We thank Ms Cheenee Calantoc of the Research Grants Administration Office of the University of the Philippines Manila for her assistance in the review of the literature.

Contributors MASS was the attending endocrinologist and RGB was the endocrine fellow who took care of the patient. Both were involved in the conceptualisation of the report, collection of data and photograph, and writing of the article.

Funding The authors have not declared a specific grant for this research from any funding agency in the public, commercial or not-for-profit sectors.

Competing interests None declared.

Patient consent for publication Obtained.

Provenance and peer review Not commissioned; externally peer reviewed.

\section{ORCID iD}

Mark Anthony Santiago Sandoval http://orcid.org/0000-0003-0622-8287

\section{REFERENCE}

1 Slominski A, Tobin DJ, Shibahara S, et al. Melanin pigmentation in mammalian skin and its hormonal regulation. Physiol Rev 2004;84:1155-228.

Copyright 2020 BMJ Publishing Group. All rights reserved. For permission to reuse any of this content visit

https://www.bmj.com/company/products-services/rights-and-licensing/permissions/

BMJ Case Report Fellows may re-use this article for personal use and teaching without any further permission.

Become a Fellow of BMJ Case Reports today and you can:

- Submit as many cases as you like

- Enjoy fast sympathetic peer review and rapid publication of accepted articles

Access all the published articles

Re-use any of the published material for personal use and teaching without further permission

\section{Customer Service}

If you have any further queries about your subscription, please contact our customer services team on +44 (0) 2071111105 or via email at support@bmj.com.

Visit casereports.bmj.com for more articles like this and to become a Fellow 